\title{
Does Family Longevity Goals Moderates Family Involvement Towards Business Performance?
}

\author{
A Case of Bandung Family Firms
}

\author{
Raissa Rachelia ${ }^{1}$ Amadea P. Yanson ${ }^{1}$ Chrisanty V. Layman ${ }^{1, *}$ \\ ${ }^{1}$ Pelita Harapan University, Indonesia \\ "Corresponding author. Email: layman@uph.edu
}

\begin{abstract}
Indonesia's family businesses have always had an important role to the stability and growth of the economy. Family involvement in the management of family firms is deemed as one of the key differentiators to non-family businesses. With such family involvements, family firms require trust and commitment to ensure the family's longevity and prosperity. However, such dynamics may have an influence on family firm performance. Previous studies have shown inconsistencies regarding how family involvement in management would influence firm's performance, all showing possible positive, negative, and to no significant influence. Therefore, this study seeks to gain some clarity on the influence of family involvement with family longevity goals towards family firm performance. The study includes 200 respondents, all involved within the management of family firms, located in Bandung, one of the family firm populated cities in Indonesia. The study uses quantitative methods, where data is analyzed for reliability and validity using SEM. The result of the study shows that there is no significant influence between family involvement in management to firm performance. However, when family involvement in management is in line with the family longevity goals, there is significant positive influence on firm's performance. This study seeks to contribute to Indonesia's family firm management by aligning family involvement to ensure the achievement of positive family firm performance.
\end{abstract}

Keywords: Family Business, Family Involvement, Family Longevity Goals, Firm Performance, Indonesia.

\section{INTRODUCTION}

According to the data from Price Waterhouse Cooper 2014 (PWC), more than 95\% of businesses in Indonesia are family businesses, while about $0,2 \%$ from the total population that is running a family business. The total wealth of these family businesses has reached 134 trillion US\$, contributing towards $25 \%$ of Gross Domestic Product (GDP) di Indonesia [1]. This certainly shows that family businesses have an important role to the country's economy.

Family involvement in management of a family businesses is the key in differentiator from non-family businesses. Family involvement in management also includes family's participation in taking strategic decisions [2] The importance of family involvement in the function and performance of family businesses has attracted many scholars in research studies. However, most of these studies are conducted in countries such as America or Europe while studies in developing countries are scarce [3].

Family businesses puts importance in the continuity of business in the family, financial security, and family's longevity [4], [5]. However according to the survey that is done by PWC in 2014, 16\% of the family business have priority in firm goals if it is in line with the family's long-term future and success. Therefore, researcher's view that family involvement influence performance. However previous studies have shown inconsistencies regarding how family involvement in management would influence firm's performance, all showing possible positive, negative, and to no significant influence. 
This study aims to explain and analyze the influence family involvement to firm performance in family businesses in Bandung. Furthermore, the study seeks to discover whether family longevity goals have a role in moderating the family involvement to firm performance. This research seeks to contribute to family businesses in strategizing to achieve firm performance with the formulation of family longevity goals.

\section{LITERATURE REVIEW}

\section{Family Involvement in Management and Performance}

The most important resource to achieve firm performance is human resources [2]. Family members can become qualified human resources for family firms due to their good commitment to be an employee, possessing similar values, familiar in family values, holding the family's dream, vision and mission [6]. Although family involvement could be apparent in the ownership and management of family businesses, however, its influence on firm performance is still a debate [7]-[9]. Previous research shows that the result between family involvement's influence on firm performance is positive [10], meanwhile other studies show contradicting negative influences, positive and negative [11], and no significant influence at all [12].

There are two main theories that generally explain the relationship between family involvement with firm performance: agency theory and stewardship theory [13]. Agency and stewardship theory look at two different side of perspective in terms of the relationship between family involvement with firm performance [14]. Past research on family business with agency theory, shows that family business has lower agency cost than non-family business and has the most efficient organizational form [15]. This is due to the similar values found between owner and manager[16] and strong trust between family members. However, agency cost can happen could also occur within intra-family members due to lack of supervision [17].

On the other hand, stewardship's theory, family members sees their family business as part of themselves. This theory suggests high involvement of family members because of the sense of belonging that can motivate family members in firm to act toward firm interest [13]. When family managers are more focused to interest that tend to be non-economics, it actually increases a stewardship attitude that results in better performance, this is where the family member interests are in line with the owner of the firm.
Family involvement in family business is different because each family has different beliefs and paradigm. Indonesia holds a familial discipline that requires keeping a good relationship with each other, being honest and trusting each other. Based on this context in Indonesia, this research takes the hypothesize similarity in family's manager's interest with firm goals that results in family involvement having positive influence to family business's firm performance.

\section{Family Longevity Goals}

Family business's goals are usually influenced by family involvement with commitment [18]. Adopting non-financial goals happens when the family business has unique goals such as harmony that happens between family members, entrepreneurial tradition in family, social status in a community. When non-financial goals are adopted, they become firm goals, it makes its owner and executive family members not only pay attention to firm interest, but also what external party that related to the firm need[19].

Contingency theory states what influences one variable against others variable depends on the third variable [5]. This is seen in the context of family businesses, where the tendency of how family managers would act, where the relations between firm performance and family involvement is dependent to certain contingency that is in family business. According to that theory, so, the second hypothesis is made, where is relationship between family involvement with firm performance is moderated by family longevity goals.

\section{Performance in Family Business}

In the family business context, firm performance is measured multidimensionally, due to the dynamic complexities of the family business [20]. Discussing the complexity of family business, a conceptualization of business performance that includes not only financial indicators, but also non-financial and operational indicators. 


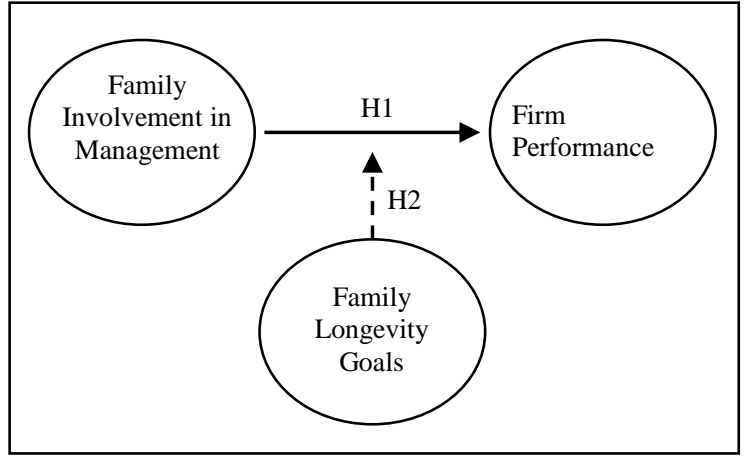

Figure 1. Research Model

Based on theories according to experts, it can be said that business performance is what has been achieved by the firm seen from ROI, growth in firm sales, market share, quality of services or products offered by the firm, operational efficiency of the firm, and income in the firm. Control is also needed to find out how the effects of family manager involvement appropriately. That way, control will be carried out on the firm industry, education from managers and owners, firm location, firm age, and firm size as shown in Fig.1.

\section{METHODOLOGY}

\section{Data Collection}

Data for this study is collected using questionnaires distributed through Google forms. Respondents were founders and family members that is involved in family's business firms, all based in the city of Bandung. Samples compromise of around 200 respondents. The object of this research is to examine the firm's performance. The measurement scale uses an interval scale, that is a Likert scale 1-5.

\section{Data Analysis}

This study examined descriptive statistics by looking at frequency, central tendency, and dispersion [21]. In measuring the central tendency and dispersion this study will see the average, minimum, maximum, standard deviation, and variance coefficients. The measurement tool in testing reliability and validity is by using Structural Equation Modeling (SEM) which is a statistical development that is a multivariate analysis technique that has a main component in linear regression analysis which has also become quasistandard in research [22]. Data compiled is then analyzed using Smart PLS 3.2.7 software.

\section{RESULTS AND DISCUSSION}

\section{Respondent's Profile}

The questionnaire was circulated in 220 questionnaires, but the questionnaire that could be used was only 200 respondents, namely those who were family members of the founding firm and residing in Bandung. Most respondents' profiles are male, with ages 31-40 years, S1's last education, is a firm founder, with has joined the firm $<=5$ years

\section{Firm Profile}

In this study, the author analyzes the firm profile which can be used as a reference for the sample researched in Table 1.

Table 1. Firm Profile

\begin{tabular}{|l|l|l|}
\hline \multirow{5}{*}{ Firm Industry } & Category & Percentage (\%) \\
\hline \multirow{5}{*}{ Firm Age } & Manufacturer & $13.5 \%$ \\
\cline { 2 - 3 } & Trading & $59.5 \%$ \\
\cline { 2 - 3 } & Service & $27 \%$ \\
\hline \multirow{5}{*}{ Total Employees } & $<10$ years & $39 \%$ \\
\cline { 2 - 3 } & $10-19$ years & $42 \%$ \\
\cline { 2 - 3 } & $>=20$ years & $19 \%$ \\
\hline \multirow{5}{*}{ Total involved family members } & $<=49$ employee & $52.5 \%$ \\
\cline { 2 - 3 } & $50-99$ employee & $23 \%$ \\
\cline { 2 - 3 } & $100-499$ employee & $14 \%$ \\
\cline { 2 - 3 } & $>-500$ employee & $10.5 \%$ \\
\hline & $25 \%-50 \%$ & $49.5 \%$ \\
\cline { 2 - 3 } & $51 \%-75 \%$ & $33.5 \%$ \\
\cline { 2 - 3 } & $>75 \%$ & $57 \%$ \\
\hline Family Generation & $15 t$ Generation & $5 \%$ \\
\hline
\end{tabular}




\begin{tabular}{||l|l|l|}
\hline \multirow{5}{*}{$\begin{array}{l}\text { Gross Income / Turnover per } \\
\text { year }\end{array}$} & $2^{\text {nd }}$ Generation & $36 \%$ \\
\cline { 2 - 3 } & $3^{\text {rd }}$ Generation & $4 \%$ \\
\cline { 2 - 3 } & $>=4^{\text {th }}$ Generation & $3 \%$ \\
\cline { 2 - 3 } & $<500$ Million & $26 \%$ \\
\hline & $500-1$ Billion & $26 \%$ \\
\cline { 2 - 3 } & $1-2$ Billion & $14 \%$ \\
\cline { 2 - 3 } & $2-3$ Billion & $17 \%$ \\
\cline { 2 - 3 } & $3-5$ Billion & $7 \%$ \\
\cline { 2 - 3 } & $>5$ Billion & $10 \%$ \\
\hline
\end{tabular}

Therefore, it can be concluded that most industrial firms are trading firm, with a firm age of 10-19 years, the number of workers $<=49$ employees, the number of family members involved in the firm is $<25 \%$, the first generation, and with gross income or turnover of $<500$ million and $500-1$ billion. To obtain the distance value in, the researcher carries out the maximum value reduction with the minimum value from the data [21].

\section{Results and Discussion}

This study replicates the research model from Y. Kim and F. Y Gao (2013) [5]. Hypothesis test results that have been carried out using the bootstrapping method with Smart PLS 3.2.7 software show that not all hypotheses are accepted.

The first hypothesis, with the statement of family involvement in management has a positive influence on the performance of the firm has a t-value of 1,086 which means less than the value of 1.96. Thus, based on the limits specified in this study, it can be concluded that the first hypothesis is not supported. The test results indicated that the first hypothesis is not accepted. In other words, increasing family involvement does not necessarily make family performance. The influence of family involvement on business performance is reinforced by the decision-making process of the board of directors and their tasks .

This further proven by research conducted in which family business prefer to hire professionals rather than recruiting family members as their top management team due to lack of professional family members, or it can be said, their performance is not good when compared professional workforce and not from family members. Poor performance can cause business performance to decline.

The results also show that most respondents had a percentage of family members involved in the family firm is under $25 \%$. According to Susanto et al (2013), this can also happen because the majority of respondents of the firm are 10-19 years old, where the firm is still in the go-go stage [6]. The go-go stage is the stage where the firm begins to develop, because it requires a qualified workforce to achieve corporate stability. That way, it is likely that a family firm recruits a professional to help the firm stabilize.

On the other hand, the second hypothesis, with the statement of the purpose of family longevity has a moderating effect on the performance of the firm by having a t-value of 2.313. which means it exceeds the value of 1.96. Thus, based on the limits specified in this study, it can be concluded that the second hypothesis is supported. Based on the results of hypothesis testing listed above, it shows that the second hypothesis is supported. Therefore, when family involvement is included with the emphasis on family longevity goals, the higher the performance of the business.

This statement is supported by contingency theory according to Kim and Gao (2013), where the theory can be used to determine the impact of one variable on other variables depending on the third variable, where the family longevity goals is a contingency on the relationship between family involvement and business performance [5]. When the family longevity goals are in line with family member managers' goal, they will maximize their performance which will affect business performance better than the previous one. Not only that, according to Charbel et al., (2013), family managers do tend to behave as a steward [15].

\section{CONCLUSION}

This research contributes to family firms, especially in measuring firm performance with the existence of family involvement in management and with the family longevity goals. In the first hypothesis, where the hypothesis is not accepted, so to improve the performance of the firm it would be nice if the owner of 
a family firm also involved managers who were professionals and did not come from family members. In order to improve business performance, it is necessary to choose managers based on their competencies, whether they are able to lead the firm and set a good example for their subordinates.

The statement that the involvement of family members in firms that have family longevity goals will result in stronger corporate performance. It means that the owner of the firm must make the family members involved in the firm have a family longevity goals and in accordance with the objectives of the owner of the firm, so that there is an increase in business performance.

There are various ways to achieve this by for example the owner of the firm can hold family meetings regularly so that family members involved in the firm can better direct their goals towards the family longevity goals. In addition, at the meeting, not only directed them to aim for prospering the family or talking about business, but also for the longevity the family.

\section{LIMITATION AND CONTRIBUTION}

Limitations in this research includes using only one dependent variable in discussing firm performance, while there are still other variables that can affect firm performance, such as CEO non-family involvement, firm ownership and management, innovation, corporate flexibility, firm activities, and so on. In the sample characteristics, the sample used was only the family member of the founding family firm in Bandung. So, this research does not necessarily reflect all the founding family members in the family firm.

In addition, in this research the definition of family firms in the process of distributing questionnaires has a dependence on the decision of respondents in defining their firm as a family firm or not. Furthermore, with a limited number of samples, the generality of this study is still limited and there are limited time in making this research.

\section{REFERENCES}

[1] PwC, "Survey Bisnis Keluarga 2014, Indonesia," no. November, p. Diakses tanggal 27 Januari 2015 pukul 10.07 WIB, 2014.

[2] D. Miller and I. Le Breton-Miller, "Family Governance and Firm Performance," Fam. Bus. Rev., vol. 19, no. 1, pp. 73-87, 2006.

[3] O. Kowalewski, O. Talavera, and I. Stetsyuk, "Influence of Family Involvement in Management and Ownership on Firm
Performance: Evidence From Poland," Fam. Bus. Rev., vol. 23, no. 1, pp. 45-59, 2009.

[4] G. T. Lumpkin, W. Martin, and M. Vaughn, "Family Orientation: Individual-Level Influences on Family Firm Outcomes," Fam. Bus. Rev., vol. 21, no. 2, pp. 127-138, 2008.

[5] Y. Kim and F. Y. Gao, "Does family involvement increase business performance? Family-longevity goals' moderating role in Chinese family firms," J. Bus. Res., vol. 66, no. 2, pp. 265-274, 2013.

[6] A. B. Susanto and P. Susanto, The dragon network: Inside stories of the most successful chinese family businesses. John Wiley \& Sons, 2013.

[7] C. Mazzi, "Family business and financial performance: Current state of knowledge and future research challenges," J. Fam. Bus. Strateg., vol. 2, no. 3, pp. 166-181, 2011.

[8] E. H. O'Boyle, J. M. Pollack, and M. W. Rutherford, "Exploring the relation between family involvement and firms' financial performance: A meta-analysis of main and moderator effects," J. Bus. Ventur., vol. 27, no. 1, pp. 1-18, 2012.

[9] R. Garcia-Castro and R. V Aguilera, "Family involvement in business and financial performance: A set-theoretic cross-national inquiry," J. Fam. Bus. Strateg., vol. 5, no. 1, pp. 85-96, 2014.

[10] C. Gallucci, R. Santulli, and A. Calabrò, "Does family involvement foster or hinder firm performance? The missing role of family-based branding strategies," J. Fam. Bus. Strateg., vol. 6, no. 3, pp. 155-165, 2015.

[11] F. W. Kellermanns, K. A. Eddleston, R. Sarathy, and F. Murphy, "Innovativeness in family firms: a family influence perspective," Small Bus. Econ., vol. 38, no. 1, pp. 85-101, 2010 .

[12] F. Silva and N. Majluf, "Does family ownership shape performance outcomes?," J. Bus. Res., vol. 61, no. 6, pp. 609-614, 2008.

[13] J. H. Davis, M. R. Allen, and H. D. Hayes, "Is Blood Thicker Than Water? A Study of Stewardship Perceptions in Family Business," Entrep. Theory Pract., vol. 34, no. 6, pp. 1093 1116, 2010.

[14] S. Abdullah A Al Dubai, K. Nor Izah Ku Ismail, and N. Afza Amran, "Family Involvement in Ownership, Management, and Firm Performance: Moderating and Direct-Effect 
Models," Asian Soc. Sci., vol. 10, no. 14, 2014.

[15] S. Charbel, B. Elie, and S. Georges, "Impact of family involvement in ownership management and direction on financial performance of the Lebanese firms," Int. Strateg. Manag. Rev., vol. 1, no. 1-2, pp. 30-41, 2013.

[16] B. Debicki, C. Matherne III, F. Kellermanns, and J. Chrisman, "Family business research in the new millennium: An overview of the Who, the Where, the What, and the Why," Fam. Bus. Rev., vol. 22, no. 2, pp. 151-166, 2009.

[17] E. J. Poza and M. S. Daugherty, Family Business, 4th Edition, 4th ed. Cengage, 2014.

[18] J. J. Chrisman, J. H. Chua, A. W. Pearson, and T. Barnett, "Family Involvement, Family Influence, and Family-Centered Non-Economic Goals in Small Firms," Entrep. Theory Pract., vol. 36, no. 2, pp. 267-293, 2010.

[19] I. Le Breton-Miller, D. Miller, and R. H. Lester, "Stewardship or Agency? A Social Embeddedness Reconciliation of Conduct and Performance in Public Family Businesses," Organ. Sci., vol. 22, no. 3, pp. 704-721, 2011.

[20] S. Gill and P. Kaur, "Family Involvement in Business and Financial Performance: A Panel Data Analysis," Vikalpa J. Decis. Makers, vol. 40, no. 4, pp. 395-420, 2015.

[21] U. Sekaran, "Research Methods for Business A Skill Building Approach." .

[22] J. F. Hair, C. M. Ringle, and M. Sarstedt, "Partial Least Squares: The Better Approach to Structural Equation Modeling?," Long Range Plann., vol. 45, no. 5-6, pp. 312-319, 2012.

[9] A. Pnueli, In transition from global to modular temporal reasoning about programs, in: K.R. Apt (Ed.), Logics and Models of Concurrent Systems, Springer, Berlin, Heidelberg, 1984, pp. 123-144. DOI: https://doi.org/10.1007/978-3642-82453-1_5

[10] B. Meyer, Applying "Design by Contract", Computer 25(10) (1992) 40-51. DOI: https://doi.org/10.1109/2.161279

[11] S. Bensalem, M. Bogza, A. Legay, T.H. Nguyen, J. Sifakis, R. Yan, Incremental component-based construction and verification using invariants, in: Proceedings of the Conference on Formal Methods in Computer Aided Design (FMCAD), IEEE Press, Piscataway, NJ, 2010, pp. 257-256.

[12] H. Barringer, C.S. Pasareanu, D. Giannakopolou, Proof rules for automated compositional verification through learning, in Proc. of the 2nd International Workshop on Specification and Verification of Component Based Systems, 2003.

[13] M.G. Bobaru, C.S. Pasareanu, D. Giannakopoulou, Automated assume-guarantee reasoning by abstraction refinement, in: A. Gupta, S. Malik (Eds.), Proceedings of the Computer Aided Verification, Springer, Berlin, Heidelberg, 2008, pp. 135-148. DOI: https://doi.org/10.1007/978-3-540-70545-1_14 